\title{
Transition of the Higher Education to the Practically Oriented Educational Programmes
}

\author{
Vladimir Valkov $^{1} \&$ Svetlana Valkova $^{1}$ \\ ${ }^{1}$ Federal State Budgetary Educational Institution of Higher Professional Education "Dalrybvtuz", Vladivostok, \\ Russian Federation
}

Correspondence: Vladimir Valkov, 11-97 Nadibaidze str., Vladivostok, 690012, Russian Federation. Tel: 79-14-792-5435. E-mail: vlvalkov@yandex.ru

$\begin{array}{lc}\text { Received: September 4, } 2014 & \text { Accepted: November 28, } 2014 \quad \text { Online Published: April 30, } 2015 \\ \text { doi:10.5539/ass.v11n12p32 } & \text { URL: http://dx.doi.org/10.5539/ass.v11n12p32 }\end{array}$

\begin{abstract}
The study of the applied bachelor degree course is represented. It is exposed that in the Russian system of the tertiary education the qualified gap has been formed: in practice there is a lack of the educational servicing providers, who execute training of the specializations, uniting the acquisition of the practical skills and theoretical teaching. The European, Canadian and American examples are analysed. The research provides the comparative analysis of the target direction and the applied bachelor degree course. We concluded that in the conditions of the modern life the development of education, and rapid tempos of technology modernization, the top priority is given to the training of graduates, who possess the skills and abilities of the professional adaptation in the rapidly changing world. It is solved which model of education must be preferential today in order to be demanded and employed. The education becomes the means for the most adequate reflection of the market economy and the new society requirements.
\end{abstract}

Keywords: transport, applied bachelor degree course, professional competences, state-private partnership

\section{Introduction}

The considerable changes take place today on the local and regional labour markets in Russia. In the process of transition from the planned market economy to the open one the demand for labour and structure of the population employment noticeably changed. Moreover, these changes continue to take place today almost in all sectors of the economy, including the area of water transport. The key changes in the employment are (Further education):

- Restructuring of the industries and creating the new professions;

- Essential expansion of the servicing sector at reduction of the employment;

- Redistributing the labour from the low-qualified professions in the favour of highly-skilled ones with considerable increase of the wage in latter ones;

- Increasing the mobility of labour resources.

The skills, necessary in the framework of the new profession, are noticeably distinguished from those ones, which were necessary in the old now demanded professions. In all areas of economy the mechanical manual labour is replaced by the automated one. Particularly, it is noticeable in the area of organization of transportations with water transport, where the level of complex mechanization frequently reaches $100 \%$. The intensive development and expansion of the service (servicing) sector in the country included redistribution of the labour resources in favour of this area. Thus, redistribution of the labour in the country was caused by the increase of the demand for certain skills and reduction of the demand for others. Today the new skills, more exactly their set reflected in the competences of the future employee and including the basic knowledge and practically oriented professional skills - specific/technical knowledge, - are demanded (Gimpelson, 2007).

The basic knowledge is writing and mathematical literacy, social and communicative opportunities (Peculiarities of the higher education system).

The specific technical knowledge is the set of skills, which allow the individual successful execution of the professional tasks (Rutkowski, 2009). 
In the Russian literature the connection between professional skills and individual productivity is traced. In this perspective the skills are the ability to transform their knowledge and skills into the professional result. In the conditions of the modern development of education, and the rapid tempos of technology modernization, the top priority is given to the training of graduates, who possess the skills and abilities of professional adaptation in the rapidly changing world. The education becomes a means for the most adequate reflection of the market economy and new society requirements. The changes of the education bases are accompanied by the global processes of education result reorientation (Tan, 2007).

The requirements, made by the employers to their employees, are increased every day. Many directions, claimed on the modern enterprises of the water transport area, require the essentially higher level of qualification, than before. The modern specialist must know and possess the abilities to manage the high-technological equipment, understand the drafts, be able to read instructions in foreign languages, work with the information and navigation systems and aspire to self-perfection etc. Practically this must be high-skilled diversely developed specialist, who possesses the set of the professional competences.

\section{Methods}

The system of the tertiary education in the Russian Federation includes the elementary professional (EPE), secondary professional (SPE) and higher professional education (HPE). The skills and competences of the graduates of the programmes of professional training are defined by the education standards of each of three education levels. At that the gap between educational programmes that is expressed in the difference of skill and competence set in the graduates at different levels becomes more felt. The programmes of EPE are directed on the training of the skilled employees, SPE -middle- level narrow specialists, and the system of HPE guides the training of the high category specialists, as a rule, oriented on the leading or scientific-theoretical work.

Thus, in the Russian system of the tertiary education the qualified gap was formed: in practice there is the lack of the educational servicing providers, who execute training on the specialties, uniting the acquisition of the practical skills and theoretical education. Officially this niche is taken by SPE. In fact, it remains free, as the system of SPE doesn't manage its task. In the Russian labour market recently the serious lack of the high-skilled specialists of the technical professions has formed. So, the level of employment exceeds the level of unemployment only among employees, who have the higher and secondary professional education. Consequently, the availability of the professional education reduces the opportunity of falling into the category of the unemployed.

The foreign countries began to solve the analogous problem in the second half of the last century. Presently, the training on such specialties is executed within the framework of the applied bachelor degree course (ABDC). On the assumption of foreign experience the qualified niche, existing in the Russian system of professional education, can be filled in by the way of implementation of the programmes of professional training similar to the applied bachelor degree course (Volberda, 2004).

Table 1. The comparative analysis of the target direction and the applied bachelor degree course

Target direction Applied bachelor degree course

The target set, as a rule, exists in the branch higher In 2014 the target set in all higher education establishments educational establishments is planned

The small competition at entrance

Opportunity of continuing education

Assignment from the concrete organization

Organization pays out or tries to allocate funds from the budget

Working at the enterprise during 3 years

Organizations don't participate in the development of the Organization participates in the developments of the educational programmes

Additional entrance examinations are absent
The small competition at entrance

Opportunity of continuing education

Assignment from the concrete organization

At the expense of budget

Enterprises are interested in the employees programmes in the part of professional theoretical training

Opportunity of the conduction of the additional entrance examinations of the creative and/or professional direction at admission for study 
The programmes of the applied bachelor degree course in the countries of the Western Europe relate to the system of the higher non-academic education. They are realized both in the universities together with the programmes of the academic Bachelor degree course, and in the special establishments of the professional education. According to the International standard classification of education (ISCE) of UNESCO the programmes of the applied bachelor degree course correspond to the level $5 \mathrm{~V}$ that is described in ISCE as practically oriented programmes of the tertiary education first stage of within the term of education from two up to four years.

Training on the BDC programme in many European countries began at the end of previous century. In some cases for realization of the programmes the educational establishments of the new type were created, in which the theoretical courses were closely connected with the development of professional skills. Thus, the following establishments were formed (University of New Brunswick, VAMK, and University of Applied Science):

- Professional education colleges (further education colleges) in Great Britain (from the applied institutes and technological schools) in 1960;

- Specialized higher educational establishments (Fachhochschulen) in Germany in 1970-1971;

- State colleges in Norway in 1994 (as a result of amalgamation of 98 professional colleges);

- Polytechnics in Finland in 1991 (as a result of amalgamation of 250 institutions of the secondary professional education);

- Specialized higher educational establishments (Fachhochschulen) in Austria in 1993 etc.

Thus, the tertiary education system is expanded to three levels:

- The first level - universities, considerable part of which is oriented on the scientific-research activity;

- The second level - educational institutions of the applied sciences (practically oriented bachelor degree course);

- The third level - professional educational institutions, carrying out training on the technical specialties.

In order that the Russian programmes of the bachelor degree course become the basis for realization of BDC programme, it is necessary to change their content radically, and make them practically oriented. The modern Russian programmes of the bachelor degree course secretly suppose the further education in the magistracy. They are intended for the training of further researches and almost don't give the applied skills and knowledge. The biggest part of the programme is made of the theoretical courses - these programmes are intended for the training of a bachelor, whose basic activity content is solution of the heuristic tasks, execution of the problematic and creative nature work (immediately after obtainment of the bachelor's degree or after continuation of the education in higher educational establishment).

The higher educational establishments were the start platform for the development of country transport complex. However, the absence of the complexity of the scientific researches, and the low effectiveness of scientific development implementation, reduction of the young specialists' quantity, entering for post-graduate study and doctoral training, and want to devote them to the scientific work, remain the serious problem.

One of the tasks of the higher educational establishments, which train specialists in the area of transport management is the usage of the students' scientific-research potential, namely, detection of the talented students and post-graduate students, and their motivation to the choice of academic carrier by the way of involvement to the scientific, pedagogical work, participation in the scientific competitions, conferences, development of the innovation projects, and execution of the economic contractual works. Realization of the majority of scientific-educational projects requires cooperation of higher educational establishments with the enterprises and organizations of the branch.

The mechanism of effective interaction of business and educational community can become the state-private partnership (SPP), especially at realization of the innovation educational programmes and technologies.

SPP can be defined as a system of the long-term relations between the state and representatives of the private sector on realization of the combined projects based upon distribution of the profits or non-material benefits, expenditures and risks. SPP in the area of education represents the alliance between the state and business for the purposes of the educational project realization based upon the legislative acts and special agreements. Notwithstanding the practice of mechanism application in SPP is mostly developed namely in the transport complex, the SPP mechanisms in the area of training the staff for branch still works weakly. The low investment attractiveness, the absence of the commercial interest, the absence of the legal base and lack of the high-skilled 
specialists in the area of creation and management of the projects restrain the financial support of the educational complexes by shipping companies, ports and dock plants.

We suppose that the applied bachelor degree course can be implemented in the Russian higher educational establishments. The main problem is the necessity of the considerable expenditures on creation of the material-technical base for practically oriented education that higher educational establishments don't have in majority.

The second possible variant of realization of ABDC in Russia is creation of the corresponding courses on the basis of the education programmes of SPE.

The programmes of the secondary professional education, existing in Russia, in their essence are the analogues of the European programmes of the applied bachelor degree course. They have practically oriented nature and allow graduates entering the labour market directly after teaching (don't require and suppose the further education). However, the Russian programmes of SPE have weak (implicit) connections with the labour market: after graduation the students must employ themselves, and appeal into the employment service. Moreover, the programmes considered differ from the European ABDC programmes in relation to the content of competences, which are mastered in the process of study. Except for the executive skills the APDC programmes suppose teaching the organizational and managerial competences. The graduates of the applied bachelor degree course programmes are high-skilled specialists, able not only to execute the instructions and follow the regulatory documents, but to take initiative in their hands, think out the new ways of solving the tasks, and create something principally new.

Let's consider the similarity and difference of the foreign ABDC programmes and the Russian professional education more properly.

The programmes of the secondary professional education on the level of training, which exist today in Russia, are divided into the programmes of the basic and increased level.

The educational standards of the SPE basic and increased level suppose execution of the programmes of similar activity types by the graduates: industrial-technological, organizational-managerial, constructive-technological, and experienced-experimental. However, the SPE increased level is more advanced and provides the students with wider spectre of competences beginning from the executive to managerial ones.

Thus, the SPE programmes of the increased level are actually direct analogues of the foreign applied bachelor degree course programmes. As it was said above, both of them have the practically oriented nature and allow a graduate executing the direct exit on the labour market, provide finished specialties, i.e. don't require and suppose the further education. The unessential corrections of SPE increased level programmes transform them into ABDC programmes. However, unfortunately, the SPE programmes of the increased level are not realized according to key directions, as machine-building, country and fish economy, construction and architecture, service, automation and management, instrument-making, metallurgy, energetic etc.

\section{Results}

Summarizing the above-mentioned, we can answer exactly the question "What model of education must be preferential today in order to be demanded and employed?"

The target education have been existing for many years already, and the certain percent of the students was chosen and without fail would choose namely this model of education. It is experienced by ages and generations, and there is nothing unknown and frightening in it. Nevertheless the applied bachelor degree course still didn't recommended itself, as approbation of this model has not been finished yet. This novelty involves variety in training of the practically oriented workers to the activity, connected with implementation, adaptation, optimization of the innovation technologies and technological processes. However, not every educational establishment can implement the applied bachelor degree course in all planed results. For this purpose it is necessary:

- To have staff, capable to provide studying the demands of region labour market, and programme development, including professional modules, organization and content of the theoretic and practical component of the programme;

- That the staff potential of the educational establishment included not only the teaching staff, but the representatives of employers, having the experience of practical professional activity, connected with programme realization;

- To possess materially technical and scientific-methodological base, necessary for programme implementation; 
- To have the base of practices on the enterprises, the newest equipment, laboratories and workshops, computer equipment, teaching-books, trainers, access to the corresponding new literature and electronic carriers;

- To have the productive mechanisms of employment of the graduates, agreements with employers;

- To renovate, and specify the results of programme acquisition annually;

- To use laboratories, training ground of the enterprises, base of practices;

- To take part in the practice management;

- To develop the tasks for thesis projection and programmes of the state and summary attestation and participate in its holding;

- To organize further education courses of the teachers and their probations.

The needs of modern Russian labour market are different, but the unity of employers is revealed in one that there is a need in high-skilled staff beginning from the worker, process-technician to the scientific investigator.

One of the ways leading to the increase of accessibility of the qualitative education that corresponds to the requirements of innovation development of the Russian economy, modern society and human demands is the development of the educational programmes variety.

Mission of the applied bachelor degree course programme lies in following:

- To overcome the risk of loss of the practically oriented programmes at introduction of the level higher education;

- To reduce the expenditures levels of the employers' organizations upon the end of graduates' teaching;

- To adapt the educational programmes of higher educational establishments to the order of the practically oriented results, which corresponds to the requirements of professional standards;

- To reduce the terms of young people entrance into the labour market in the conditions of demographic crisis and staff ageing;

- To reduce the risk of the graduates' unemployment;

- To expand the variety of educational programmes and reduce their doubling on the level of secondary and higher professional education.

What kind of education model can "grow" such specialist, and how to teach students in order to realize and employ them on the labour market is the essential issue of the industrial world. In the present conditions of education development and quick tempos of technology modernization, the top priority is given to training of the graduates, who possesses the skills and abilities of the professional adaptation in the rapidly changing world. The education becomes a means of the most adequate reflection of the market economy and new society demands.

\section{References}

Brunello, G. (2009). The effect of economic downturns on apprenticeships and initial workplace training: A review of the evidence. Journal of Empirical Research in Vocational Education and Training, OECD, 1, 11-16.

Further education. Retrieved from http://au.encarta.msn.com/encyclopedia_781538887/Further_Education.html

Gimpelson, V., Kapelyushnikov, R., \& Luk'ianova, A. (2007). The demand for labour and qualification in the industry: between the deficiency and surplus. Moscow: SU VSHE.

Peculiarities of the system of higher education. Retrieved from http://is.znanie.info/rus/education/28.html

Rutkowski, J. (2009). Demand for skills in ECA: Main trends and patterns. Human Development Unit, Europe and Central Asia Region, World Bank, Washington, DC.

Schools in the USA. Retrieved from http://www.schoolsintheusa.com/CommunityCollegeFacts.cfm

Tan, H., Savchenko, Y., \& Gimpelson, V. (2007). Skills shortages and training in Russian enterprises. Moscow: SU - HSE.

University of New Brunswick, CANADA. Retrieved from http://www.unb.ca/

VAMK, University of Applied Science. Retrieved from http://www.puv.fi/en/

Vocational training in higher education and labour market outcomes: evidence from the "new vocational bachelor degree" in France. GIRET Jean-Francois Cereq, PPT presentation, 2006. 
Volberda, H. W., \& van den Bosch, F. A. J. (2004). Rethinking the Dutch innovation agenda: Management and organization matter most. Essay for the Ministry of economic affairs' innovation lecture. Erasmus Strategic Renewal Centre, Rotterdam School of Management.

\section{Copyrights}

Copyright for this article is retained by the author(s), with first publication rights granted to the journal.

This is an open-access article distributed under the terms and conditions of the Creative Commons Attribution license (http://creativecommons.org/licenses/by/3.0/). 